Djuma, A. W., Yudhaswara, N. A., \& Dardeau, S. P. (2020). Relation between Alcohol Consumption and Impaired Liver Function. JURNAL INFO KESEHATAN, 18(2), 163-170.

Jurnal Info Kesehatan

Vol 18, No 2, December 2020, pp. 163-170

P-ISSN 0216-504X, E-ISSN 2620-536X

DOI:10.31965/infokes.Vol18Iss 2.474

Journal homepage:http://jurnal.poltekeskupang.ac.id/index.php/infokes

RES EA R C H

Open Access

\title{
Relationship between Alcohol Consumption and Impaired Liver Function
}

\author{
Agustina W. Djuma $^{1 a^{*}}$, Novian A. Yudhaswara ${ }^{1 b}$, Suzanne Patricia Dardeau ${ }^{2 c}$ \\ ${ }^{1}$ Department of Medical Laboratory Technology, Poltekkes Kemenkes Kupang, Kupang, East \\ Nusa Tenggara, Indonesia \\ ${ }^{2}$ Cleveland Chiropractic College-Kansas City, USA \\ ${ }^{a}$ Email address: hdhelmydj@gmail.com \\ b Email address: novianagni@yahoo.com \\ c Email address: dr.sdardeau@gmail.com
}

Received: 11 September 2020 Revised: 22 December 2020 Accepted: 25 December 2020

\begin{abstract}
East Nusa Tenggara is a province of high alcohol abuse in Indonesia. Ngada Regency has a prevalence of $38.8 \%$. The high prevalence is inseparable from traditional factors and sociocultural norms which strongly influence the habit of consuming alcohol, the cold temperature in this area further strengthens this habit. The impact of alcohol consumption is the emergence of various types of diseases, one of which is impaired liver function such as alcoholic liver disease. The objective of this study is to determine the relationship between alcohol consumption and impaired liver function in communities in Bajawa and Golewa Districts, Ngada Regency. This research method is an observational analytic with cross-sectional design. The research subjects were 55 people who consumed alcohol in Golewa and Bajawa Districts, who had met the inclusion criteria. Alcohol consumption was measured by the AUDIT (The Alcohol Use Disorders Identification Test) questionnaire, while the parameter for liver disorders was the level of Gamma Glutamyl Transferase (GGT). The prevalence of liver dysfunction based on GGT examination was $15 \%$. Meanwhile, the relationship between alcohol consumption and impaired liver function was tested with the Spearman correlation with $\alpha 0.05$, the correlation value was $\mathrm{p}=0.413$, which means it has a moderate or significant, not too strong relationship. It is recommended that the people of Ngada Regency reduce alcohol consumption so that it can reduce the risk of impaired liver function.
\end{abstract}

Keywords: Alcohol Abuse, Liver Disorders, Gamma Glutamyl Transferase

\section{*Corresponding Author:}

Agustina W. Djuma

Department of Medical Laboratory Technology, Poltekkes Kemenkes Kupang, Kupang, East Nusa Tenggara, Indonesia. Email: hdhelmydj@gmail.com

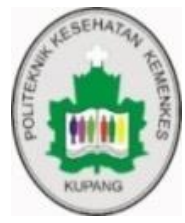

(C)The Author(s) 2020. This article is distributed under the terms of the Creative Commons Attribution 4.0 International License (http://creativecommons.org/licenses/by/4.0/), which permits unrestricted use, distribution, and reproduction in any medium, provided you give appropriate credit to the original author(s) and the source, provide a link to the Creative Commons license, and indicate if changes were made. The Creative Commons Public Domain Dedication waiver (http://creativecommons.org/publicdomain/zero/1.0/) applies to the data made available in this article, unless otherwise stated. 


\section{INTRODUCTION}

Liquor is a drink containing alcohol which is a psychoactive substance that is addictive. Alcohol abuse has been associated with health hazards including the risk of various mental health illnesses, accidents and social dysfunction. Chronic alcohol consumption can cause multisystemic diseases and pathophysiological changes in most organs, for instance, liver cirrhosis, breast cancer in women, colon cancer, kidney disease, pancreatic disease, diabetes, immune system deficiency, osteoporosis, indigestion, hypertension, heart disease, arthritis and central nervous system disorders (Purbayanti \& Nafarin, 2019).

Through the Basic Health Research 2018, the proportion of alcoholic drink consumption behavior in the last 1 month of the population aged $>10$ years, the province of East Nusa Tenggara has $28.8 \%$ male, $2.86 \%$ female characteristics, with the highest age group 20-24 years $25.08 \%$ with a high school graduation level of $21.09 \%$ and rural residences as much as $\mathbf{1 5 . 7 6 \%}$ (Kemenkes, R. I., 2018). In the personal study at the level of education, the prevalence of drinking alcohol is high in those who have graduated from junior high school and graduated from high school. Moreover, the prevalence of alcohol drinkers in rural areas is higher than urban matters (Pribadi, 2017). The prevalence of alcohol consumption in East Nusa Tenggara Province in 2018 increased to $15.6 \%$ from previous studies, while the most alcoholic drinks consumed by the community are traditional drinks, 49\% (Kemenkes, R. I., 2018). The high level of alcohol abuse in East Nusa Tenggara Province can affect the health, social and economic sectors of the local community and hamper community development (Madureira-Lima, 2018). The high prevalence in Ngada Regency is inseparable from traditional factors and socio-cultural norms which strongly influence the habit of consuming alcohol and the cold temperatures in this area further strengthen this habit. The tradition of drinking alcohol at every party (custom) and before conducting mutual cooperation activities is still maintained. There are various types of diseases caused by alcohol consumption, one of which is impaired liver function such as alcoholic liver disease (Triyono, et. Al., 2014; Fuster, \& Samet., 2018).

Alcoholic liver disease (PHA) is a dysfunction of the liver that results from prolonged consumption of a certain amount of alcohol. Alcoholic liver disease is divided into fatty liver, alcoholic hepatitis and cirrhosis. Fatty liver is common in $>90 \%$ of recurrent and heavy alcohol drinkers. Of those heavy alcohol drinkers, about 10-30\% will develop alcoholic hepatitis, and will continue to develop cirrhosis if there is no intervention. The prognosis of severe PHA is poor, where the mortality rate of cirrhosis patients in 4 years is almost 60\% (Longo, et. al., 2012; Kourkoumpetis, 2019).

Gamma-Glutamyl Transferase (GGT) is an enzyme that is located on the outer surface of the membranes of various cells. Mammalian GGT is a glycoprotein dimer with a molecular weight of $68 \mathrm{kDa}$ consisting of 2 subunits: a large subunit $46 \mathrm{kDa}$ and a small subunit $22 \mathrm{kDa}$. However, depending on the degree of glycosylation, molecular weights have been reported to vary between 38 to $72 \mathrm{kDa}$ for large GGT subunits and 20 to $66 \mathrm{kDa}$ for small GGT subunits. The large subunit has an intracellular N-terminal sequence, a trans membrane hydrophobic domain and an extracellular domain and is responsible for the anchoring of GGT on the surface of the cellular membrane while the small subunit hosts the active center of the enzyme (Castelano \& Merlino, 2012). GGT is a biomarker that is mostly secreted by the liver and is found in human epithelial cells. GGT plays an important role in the metabolism of glutathione, an important component of the anti-oxidative process (Whitfield, 2001). 
Based on this study, it is necessary to conduct research to examine the relationship between alcohol consumption and liver dysfunction in communities in Bajawa and Golewa districts, Ngada Regency in 2018. The novelty of this study examines the large amount of alcohol consumed by users and the results of liver dysfunction tests, which is Gamma Glutamil Trasferase (GGT).

\section{RESEARCH METHOD}

The type of research used in this study was an observational analytic study with a cross-sectional design with the independent variable being the daily consumption of local community alcohol obtained by the AUDIT questionnaire and the dependent variable was impaired liver function determined by GGT levels taken from venous blood samples. This research has received research approval from the National Unity Agency, Politics and Community Protection, Ngada District Government No.071/ BKPL/712/IX/2018. The research subjects were 55 people who consumed alcohol in Golewa and Bajawa Districts, Ngada Regency, taken in 2019 with a purposive sample technique. The sample consisted of 20 research subjects from Golewa District, and 35 research subjects from Bajawa District, East Nusa Tenggara Province with the inclusion criteria of men and women, physically fit, aged 20-60 years and consumed alcohol in the last 2 years, not in a state of illness, there is no history of liver disease, heart disease, muscle disorders, hepatitis, and kidneys, is not in the period of treatment and is willing to be a research subject. Blood tests to test for liver dysfunction were employed at the ASA laboratory in Kupang. The data were analyzed using univariate and bivariate analysis and to determine the relationship between alcohol consumption and impaired liver function, the Spearman Correlation test was administered.

The alcohol use disorder identification test (AUDIT) is a screening tool with 10 question types developed by WHO with the aim of assessing alcohol consumption, drinking behavior and alcohol-related problems (Babor, et. al., 2001). AUDIT (The Alcohol Use Disorders Identification Test) has been validated across gender and various racial/ethnic groups in the world so that it can be used as a parameter of alcohol consumption (Higgins-Biddle \& Babor, 2018).

GGT is widely found in the liver and a little in the tissue. The liver has one function, which is detoxifying toxic substances, alcohol (ethanol) is a toxic substance for the body. Alcohol that enters the body can cause oxidative stress which causes cell damage, in the liver there is glutathione which functions as an antioxidant that protects cells from oxidative stress. If you consume excess alcohol, the liver will produce more glutathione to protect cells against oxidative stress and GGT maintains intracellular glutathione levels. Thus, when there is liver damage due to oxidative stress, GGT will appear and increase in levels. Increased GGT indicates alcohol-related liver damage (Sandi, et. al., 2020); (Gumay, \& Mustofa, 2020).

Grading/scoring for each type of question with a value range of 0-4. A total score of 8 or more is recommended as an indicator of alcohol dependence. AUDIT assessments were grouped into 4 zones based on the range of values from the AUDIT questionnaire given.

Table 1. Zone of risk level based on AUDIT value.

\begin{tabular}{ccc}
\hline Zone & Score Range & Risk \\
\hline I & $0-7$ & Low \\
\hline II & $8-15$ & Moderate \\
\hline III & $16-19$ & High \\
\hline
\end{tabular}




\begin{tabular}{lll}
\hline IV & $20-40$ & Very High \\
\hline
\end{tabular}

\section{RESULTS AND DISCUSSION}

Table 2. Distribution of frequency characteristics of research subjects based on gender.

Characteristics

Gender

\begin{tabular}{lrr} 
& Male & Female \\
\cline { 2 - 3 } Age & & \\
\hline $20-30$ & 10 & 1 \\
\hline $31-40$ & 9 & 7 \\
\hline $41-50$ & 12 & 5 \\
\hline $51-60$ & 6 & 5 \\
\hline Education & & \\
\hline Primary & 18 & 9 \\
\hline Junior High & 5 & 3 \\
\hline Senior High & 5 & 4 \\
\hline DIII-Bachelor & 9 & 6 \\
\hline Occupation & & 10 \\
\hline Official & 11 & 2 \\
\hline Farmer & 21 & \\
\hline Private & 5 & \\
\hline
\end{tabular}

As many as $67 \%$ of the subjects of this study were men with a level of primary school education as much as $49 \%$ and $58 \%$ of the research subjects were farmers. The sensitivity of this AUDIT test has a great sensitivity for various ages and has been studied (Gomez, 2006; Sandi, et. al., 2020).

Table 3. Frequency distribution of research subjects based on the AUDIT classification zone.

\begin{tabular}{crr}
\hline Zone & Frequency & Percentage \\
\hline I & 18 & $32.7 \%$ \\
\hline II & 30 & $54.5 \%$ \\
\hline III & 7 & $12.7 \%$ \\
\hline Total & 55 & $100.0 \%$
\end{tabular}

The distribution of the AUDIT determination results in table 3 shows that $54.5 \%$ is zone II, which means that half of the sample has a tendency to consume alcohol.

Table 4. Cross-tabulation data between the Audit classification zones and the frequency of GGT levels in the study subjects.

\begin{tabular}{crrr}
\hline AUDIT Classification Zone & \multicolumn{3}{r}{ GGT Level } \\
\cline { 2 - 4 } & Normal & Above normal \\
\hline I & 16 & 2 \\
\hline II & 28 & 2 \\
\hline III & 3 & 4 \\
\hline Total & 47 & 8 \\
\hline
\end{tabular}

Tabulation between samples in the AUDIT classification zone with GGT levels in table 4 shows that $485 \%$ of the samples have normal GGT levels.

Table 5. The value of the Spearman correlation calculation

\begin{tabular}{rrrrr}
\hline & & $\begin{array}{c}\text { Alcohol } \\
\text { Consumption }\end{array}$ & $\begin{array}{r}\text { GGT } \\
\text { Level }\end{array}$ \\
\hline Spearman'rho & Alcohol & Correlation & 1.000 & $.413^{* *}$ \\
\hline
\end{tabular}


Djuma, A. W., Yudhaswara, N. A., \& Dardeau, S. P. (2020). Relation between Alcohol Consumption and Impaired Liver Function. JURNAL INFO KESEHATAN, 18(2), 163-170. https://doi.org/10.31965/infokes.Vol18/ss2.474

| 167

\begin{tabular}{llrrr}
\hline Consumption & Coefficient & & \\
\cline { 2 - 4 } & Sig.(2-tailed) & 55 & .009 \\
\hline \multirow{2}{*}{ GGT Level } & N & Correlation & $.413 * *$ & 1.000 \\
& Coefficient & & \\
\hline & Sig.(2-tailed) & .009 & - \\
\hline & $\mathrm{N}$ & 55 & 55 \\
\hline
\end{tabular}

** Correlation is significant at the 0.05 level (2-tailed)

Table 5 shows that the Spearman correlation value is 0.413 from 55 samples measured by comparing the alcohol consumption taken from AUDIT with the serum GGT level.

The Ngada and Golewa people have a very strong habit of consuming alcohol, this is due to the cold temperature and customary customs for parties that allow drinking alcohol. It can be seen in Table 3 that almost more than half of the sample population is in the AUDIT zone II and zone III categories. High alcohol consumption will result in a high AUDIT value and greatly affect health, cognitive development and dementia. (Gutwinski, et. Al., 2018; Costanzo, 2019).

Chronic alcohol consumption leads to increased Gamma-Glutamyl Transferase (GGT) activity in serum which is associated with increased GGT activity in the liver. These findings suggest that the increased GGT activity commonly found in alcoholic liver disease can be considered a major cause of liver enzyme induction rather than liver cell injury, because hepatic GGT activity is increased but not reduced. In addition, at the fatty liver stage, the fetal GGT form in serum is much higher in activity than the adult form, whereas an inverse constellation can be found in patients with alcoholic liver cirrhosis. Thus, this study suggests that the determination of GGT levels in the serum of alcoholics may be useful in establishing a specific stage of alcoholic liver disease with a simple serum enzyme test (Kourkoumpetis, \& Sood, 2019; Gumay, \& Mustofa, 2020)

Serum Gamma-Glutamyl Transferase (GGT) has been widely used as an index of liver dysfunction and a marker of alcohol intake. Recent years have seen improvements in this area and advances in understanding the physiological role of fighting oxidative stress by breaking down extracellular glutathione and making amino acid components available to cells. Conditions that increase serum GGT, such as obstructive liver disease, high alcohol consumption, and use of enzyme-stimulating drugs, lead to increased free radical production and the threat of glutathione depletion. However, the product of the GGT reaction itself can cause an increase in the production of free radicals, especially in the presence of iron. The association between serum GGT and risk of coronary heart disease, type 2 diabetes, and stroke has a significant effect. People with high serum GGT have a higher mortality, partly because of the association between GGT and other risk factors and partly because GGT is an independent risk predictor (Whitfield, 2001; Haurissa, 2014; Gumay \& Mustofa, 2020).

The data on the results of the self-assessment version of the audit score in table 3 shows that $54.5 \%$ of study subjects who have a habit of drinking alcohol are in zone II that need educational/counseling interventions to simple suggestions to individuals for their behavior or drinking habits, which means intensive time is needed for the habit of drinking alcohol turned out to be less (Babor, et. al., 2001; Kuitunen-Paul \& Roerecke, 2018).

Normal GGT levels in men ranged between 11-61 $\mu / \mathrm{L}$ while in women 9-39 $\mu / \mathrm{L}$. There are $15 \%$ of study subjects with GGT levels above normal who have different 
AUDIT classification zones. It can be seen in table 4 zone III which is a zone with a level of dependence that requires counseling, individual advice to counseling, there are $7 \%$ who have GGT levels above normal, which means that even though they have a habit of consuming high alcohol, only very few exceed GGT levels in blood which means the liver function of alcohol drinkers in the area can be said to be good. GGT is an enzyme found primarily in the liver and kidneys, while low amounts are found in the spleen, prostate gland and heart muscle. Gamma-GT is a sensitive test to detect various types of liver parenchymal disease. The high GGT indicates the amount of alcohol that has entered the body during the last 1-2 weeks. High GGT is also an indicator of alcoholic liver disease (Whitfield, 2001). However, serum GGT activity was first recognized as a sensitive marker of liver dysfunction and alcohol abuse, albeit with a low specificity. GGT levels increase in a variety of physiological and pathological conditions including hepatobiliary disorders such as steatosis and viral hepatitis (Whitfield, et. al, 2001; Yang, et. al. 2019).

Table 5 shows the results of the Spearman correlation test with a value of $\alpha 0.05$, the spearman correlation value $\rho=0.413$, which indicates that there is a moderate correlation between GGT levels and alcohol consumption habits measured using the AUDIT questionnaire. The correlation number shows that the positive correlation is one-way with a significant strength of 0.009. Although the AUDIT relationship has a moderate correlation, the combination of AUDIT and GGT has a significant effect on screening for liver disease caused by alcohol abuse (Choe, et. al, 2019). The relationship between alcohol consumption and GGT has also been investigated by Luchetti M. et. al, by approaching personality traits and aspects related to self-reported alcohol, suggesting that personality slightly affects blood GGT levels (Luchetti, et. al., 2018). In contrast to the research of Kim et al, that the value of GGT is influenced by behavior (Kim, et. al, 2018).

\section{CONCLUSION}

There was a moderate or not too strong significant correlation between impaired liver and alcohol consumption. It is recommended that the people of Ngada Regency reduce alcohol consumption so that it can reduce the risk of impaired liver function.

\section{REFERENCES}

Babor, T.F., Biddle J.C.H., Saunders, J.B., Monteiro, M.G. (2001). The Alcohol Use Disorders Identification Test. Geneva: World Health Organization.

Castellano, I., \& Merlino, A. (2012). $\gamma$-Glutamyltranspeptidases: Sequence, Structure, Biochemical Properties, and Biotechnological Applications. Cellular and Molecular Life Sciences, 69(20), 3381-3394. doi: https://doi.org/10.1007/s00018012-0988-3

Choe, Y. M., Lee, B. C., Choi, I. G., Suh, G. H., Lee, D. Y., \& Kim, J. W. (2019). Combination of the CAGE and Serum Gamma-glutamyl Transferase: an Effective Screening Tool for Alcohol Use Disorder and Alcohol Dependence. Neuropsychiatric disease and treatment, 15, 1507-1515. doi: https://doi.org/10.2147/NDT.S203855

Costanzo, S., de Gaetano, G., Di Castelnuovo, A., Djoussé, L., Poli, A., \& van Velden, D. P. (2019). Moderate Alcohol Consumption and Lower Total Mortality Risk: Justified doubts or established facts?. Nutrition, Metabolism and Cardiovascular Diseases, 29(10), 1003-1008. doi: https://doi.org/10.1016/j.numecd.2019.05.062 
Djuma, A. W., Yudhaswara, N. A., \& Dardeau, S. P. (2020). Relation between Alcohol Consumption and Impaired Liver Function. JURNAL INFO KESEHATAN, 18(2), 163-170. https://doi.org/10.31965/infokes.Vol18/ss2.474

| 169

Fuster, D., \& Samet, J. H. (2018). Alcohol Use in Patients With Chronic Liver Disease. New England Journal of Medicine,379(13), 1251-1261. doi: https://doi.org/10.1056/NEJMra1715733

Gómez, A., Conde, A., Santana, J. M., Jorrín, A., Serrano, I. M., \& Medina, R. (2006). The diagnostic usefulness of AUDIT and AUDIT-C for detecting hazardous drinkers in the elderly. Aging and Mental Health, 10(5), 558-561. doi: https://doi.org/10.1080/13607860600637729

Gumay, B. S., \& Mustofa, S. (2020). Penggunaan Klinis Aktivitas Enzim GammaGlutamyl Transferase (GGT) Plasma dan Potensinya sebagai Biomarker untuk Berbagai Penyakit. Jurnal Majority, 9(1), 167-173.

Gutwinski, S., Schreiter, S., Priller, J., Henssler, J., Wiers, C. E., \& Heinz, A. (2018). Drink and think: impact of alcohol on cognitive functions and dementia-evidence of dose-related effects. Pharmacopsychiatry, 51(4), 136-143. doi: https://doi.org/10.1055/s-0043-118664

Haurissa, A. E. (2014). Gamma-Glutamyl Transferase Sebagai Biomarker Risiko Penyakit Kardiovaskuler. Cermin Dunia Kedokteran, 41(11), 816-818.

Higgins-Biddle, J. C., \& Babor, T. F. (2018). A review of the Alcohol Use Disorders Identification Test (AUDIT), AUDIT-C, and USAUDIT for screening in the United States: Past issues and future directions. The American journal of drug and alcohol abuse, 44(6), 578-586. doi: https://doi.org/10.1080/00952990.2018.1456545

Kim, J. W., Lee, B. C., \& Choi, I. G. (2017). Association of Gamma-Glutamyl Transferase (GGT) With Risk of Alcohol Use Behaviours. In European Neuropsychopharmacology, 27, S1049-S1050. Amsterdam, Netherlands: Elsevier Science.

Kourkoumpetis, T., \& Sood, G. (2019). Pathogenesis of Alcoholic Liver Disease: An Update. Clinics in Liver Disease, 23(1), 71-80. doi: https://doi.org/10.1016/j.cld.2018.09.006

Kuitunen-Paul, S., \& Roerecke, M. (2018). Alcohol Use Disorders Identification Test (AUDIT) and Mortality Risk: A Systematic Review and Meta-Analysis. $J$ Epidemiol Community Health, 72(9), 856-863. doi: http://dx.doi.org/10.1136/jech2017-210078

Longo, D., Fauci, A., Kasper, D., Hauser, S., Jameson, J., Loscalzo, J. (2012). Harrison's Principle of Internal Medicine, $18^{\text {th }}$ Edition. US: McGraw-Hill Professional.

Luchetti, M., Sutin, A. R., Delitala, A., Stephan, Y., Fiorillo, E., Marongiu, M., ... \& Terracciano, A. (2018). Personality traits and facets linked with self-reported alcohol consumption and biomarkers of liver health. Addictive behaviors, 82, 135141. doi: https://doi.org/10.1016/j.addbeh.2018.02.034

Madureira-Lima, J., \& Galea, S. (2018). Alcohol control policies and alcohol consumption: an international comparison of 167 countries. $J$ Epidemiol Community Health, 72(1), 54-60. doi: http://dx.doi.org/10.1136/jech-2017-209350

Pribadi, E. T. (2017). Alcohol Abuse in Indonesia: Determinant, SWOT and CARAT Analysis. Journal of Health Science and Prevention, 1(1), 22-37. doi: https://doi.org/10.29080/jhsp.v1i1.15

Purbayanti, D., \& Nafarin, M. R. (2019). Rasio AST/ALT pada Laki-Laki Pengkonsumsi Alkohol di Jalan Mendawai Kota Palangka Raya. Borneo Journal of Medical Laboratory Technology, 1(2), 46-51. 
Kemenkes, R. I. (2018). Hasil Utama Riskesdas 2018. Jakarta: Badan Penelitian dan Pengembangan Kesehatan.

Sandi, Y. D. L., Hidayati, L. N., \& Andarini, E. (2020). Motivasi Sosial Konsumsi Alkohol Pada Remaja. Jurnal Penelitian Keperawatan,6(2), 81-85. doi: https://doi.org/10.32660/jpk.v6i2.484

Triyono, Irdawati \& Dian N. W. (2014) Gambaran Persepsi Peminum Alkohol Tentang Dampak Kesehatan Pada Peminum Alkohol Di Dukuh Mendungan. Skripsi. Surakarta: Universitas Muhammadiyah Surakarta.

Whitfield, J. B. (2001). Gamma glutamyl transferase. Critical reviews in clinical laboratory sciences, 38(4), 263-355. doi: https://doi.org/10.1080/20014091084227

Yang, J. S., Kim, J. S., Seo, W. Y., \& Paik, C. (2016). Drinking Amount Associated with Abnormal Gamma-Glutamyl Transpeptidase Expression in Women. Korean Journal of Family Medicine, 37(1), 2-6. doi: https://doi.org/10.4082/kjfm.2016.37.1.2 